\title{
Limited Creativity as a Form of Minangkabau Traditional Randai Preservation
}

\author{
Fabio Yuda ${ }^{1 *}$, Emah Winangsit ${ }^{2}$, Hengki Armez Hidayat ${ }^{3}$, Fajry Sub'haan Syah \\ Sinaga $^{4}$
}

\author{
${ }^{1}$ Faculty of Languages and Arts, niversitas Negeri Padang, 25131, Indonesia, \\ ${ }^{2}$ Faculty of Languages and Arts, Universitas Negeri Padang, Indonesia, $\triangle$ emah_winangsit@fbs.unp.ac.id \\ ${ }^{3}$ Faculty of Languages and Arts, Universitas Negeri Padang, Indonesia, $\$$ hengkiarmezhidayat@gmail.com \\ ${ }^{4}$ Faculty of Languages and Arts, Universitas Negeri Padang, Indonesia, $\triangle$ fajry.sinaga@fbs.unp.ac.id \\ *Corresponding Author: fabioyuda@gmail.com
}

\begin{abstract}
A report from Jawa Post (2016) said that Randai as a Minangkabau traditional art is no longer performed in the conventional form. It is proved since there are many factors cause traditional art to be less attractive to the public. This concern makes Randai as one of the traditional art objects which possibly created as a form of preservation through the space of creativity. This study aims to analyze and describe the results of the Minangkabau Creative Learning process as an effort to develop traditional arts academically. The approach used in this research is creativity because a work of art has a source of ideas derived from various life phenomena to maintain ethical and aesthetic values in the process of developing traditional arts. This research is considered to be important because the results of Randai learning and development process resulted in some very innovative works that could even represent the regions at national level events.
\end{abstract}

Keywords: Randai, Creation, Creativity, Preservation

\section{INTRODUCTION}

West Sumatra province has a traditional art in the form of children play and entertainment considered as collective art that comes from the creativity of its community (Marzam, Darmawati, \& Mansyur, 2019). The community called it as Randai. There are some elements in Randai such as movement, music, a song, and stories. These elements are interrelated in the art show. A long time ago, Randai was always welcomed by various groups of people both the older and younger generation. Harun (1991, p. 83), stated that Randai in terms of meaning is defined as figurative events, while dance in Randai is defined as a complementary or attractive element. It presents a farewell greeting which makes it as a traditional theater of Minangkabau people (Sari \& Wadiyo, 2018). It also has full of wishful speeches such as figurative speech, parables, as well as folklore called "Kaba". Kaba means a story in the Minangkabau. Thus, "Bakaba" means telling stories.

A story is being told while dancing in the form of Silat movements and steps. The steps are done by some players in a circle (Wendy, 2014). Esten \& Hadi (1992) said that Randai is a dance and Kaba which is also introduced in a new form of art called aristocratic comedy. It is believed as a suitable form to the existing art form that easily accepted to create folk theater in the form of Randai (Fajry Sub'haan Syah Sinaga, 2016).
Randai used to be well-known and highly appreciated play by all society levels (Hidayat \& Arkhi, 2015). It was originally played by men, while women were prohibited from being involved in this show because it was uncommon based on customary norms. Minangkabau norm forbids women from being involved in any activities that men do. Further, the basic movements of Randai are silek. The action of the movement called basilek and this movement is only done by men (Latrell, 1999). Over time, Randai experiences a shift in the form of the show. This shift is a positive way done by its people to maintain their regional arts. On the other hand, each region has a different way of developing Randai. Women who were previously not allowed to get involved, they have an important role in Randai today (Wendy, 2014).

Further, Randai still survives until now but its enthusiasts have an impact on setbacks due to the current high-tech era, such as the use of mobile phones, laptops, computers, televisions, and gadget (Ikhsan Satria Irianto, 2017). It has been becoming a problem and anxieties for people who concern about it to develop Randai more. On the other hand, the other factor that makes Randai unpopular is the lack of government attention or various gaps that occur in the community. It seems to have an impact on Randai facilities which makes young people unable to learn it (Rustiyanti, 2014).

The Arts, Drama, and Music Department, The Faculty of Arts, Universitas Negeri Padang includes Randai as a 
compulsory subject in its curriculum. This subject must be completed by the students. They are not permitted to take a final exam without taking this lecture. In other words, this department is a place where Randai can be developed and taught to future generations. Moreover, the process of Randai academically refers to creation because each student required to be creative in making his own movements. Thus, the patterns presented can be purely the result of student creativity. However, they surely will be given an understanding about traditional Randai. This type of Randai remains as a guideline to develop the movement that later they will create Randai based on their group collection. The focus of this research is how the form of creation is done by maintaining the essence and aesthetic value of the standard contained in Randai tradition. The purpose of this research is to combine several limited creative concepts in the academic sphere as an effort to preserve the Minangkabau traditional arts in the form of Randai.

\section{METHOD}

Educational research is an activity to develop scientific knowledge toward events that attract the attention of experts (Manab, 2015). The aim is to find general principles and behavioral interpretation that can be used to explain, predict, and control events in the educational environment. The research approach used in this study was descriptiveanalytic which means that the interpretation of the content was made and arranged. The data obtained in the form of words, pictures, or behaviors were not in numbers or statistical figures, but still in a qualitative form which has a richer meaning than just numbers or frequencies (Margono, 2005, p. 39).

This study was done in the Arts, Drama, and Music Department, The Faculty of Arts, Universitas Negeri Padang, West Sumatra. This department was chosen because it is an educational college that creates art educators or teachers both in the West Sumatra and other provinces in Sumatra. It was also related to the competencies possessed by Randai instructors, for example, the basic element of Randai. Thus, the students gain Randai Creation development competency by maintaining the basic elements that Randai has. The informants in this research were last year students in the department who had taken Randai courses. The research team will conduct interviews with several lecturers and students about the obstacles in the choir learning process using number notation and beam notation. The data collection methods used in this study were observation and documentation that was related to songs and the implementation of learning in class. The observation was carried out by observing the process of learning Randai and developing Randai elements.

The process of data analysis was done by examining the obtained data in the form of interviews, observations, personal documents, official documents, pictures, photographs, and so on (Moleong in Sumaryanto, 2010: 103). The data about Randai elements and basic motion development were the main objects in this study. Besides, constraints faced in the choir learning process were analyzed to find the right steps for the development of elements through the creation of students' movements. The results of the data analysis were then compiled in the form of a report with a descriptive analysis technique based on existing theories.

\section{RESULT AND DISCUSSION}

\subsection{Creation in Tradition}

Creation was a process of developing an existing form to become a new form without eliminating the former. This process was an individual and group creativity work in meeting certain goals. The creative process was widely applied to traditional arts to make a new breakthrough so that the art had a novelty value. Ngoe Thanh, Professor at the Faculty of the performing arts, Vietnam University stated that traditional culture can be developed into a new face or otherwise it would be threatened (Thanh, 1997: 140). He saw the phenomena as an optimist phenomenon. This traditional culture can either improve itself or develop in the current condition of society (Fajry Subhaan Syah Sinaga, 2016). As a traditional art, Randai had a great opportunity to be developed into a new form (Hidayat \& Arkhi, 2015). It had been widely developed by universities and Randai groups in West Sumatra. Most agencies made a new breakthrough that later became a special feature of the group or agency (Syah, 2013).

Therefore, Randai had 4 important elements that must not be removed. These four elements were the keys why this show was so called by the name Randai. The development of these four elements had been applied in a creative process entitled "Malin Kundang's Randai distortion". This process had received an award at a creative Randai festival event in Padang Panjang in 2016. The creation process was emphasized not to eliminate important elements in Randai. It received an enthusiastic response from the audience because there were many new things made the audience were becoming interested in enjoying Randai show. There was a public thought recognized that Randai was made with the concept of novelty and turned out to be smoother and easier to understand by the general public. The concept of novelty included all four aspects of elements such as legaran/galombang (rounded movements), stories, characterizations, dialogues, and a song.

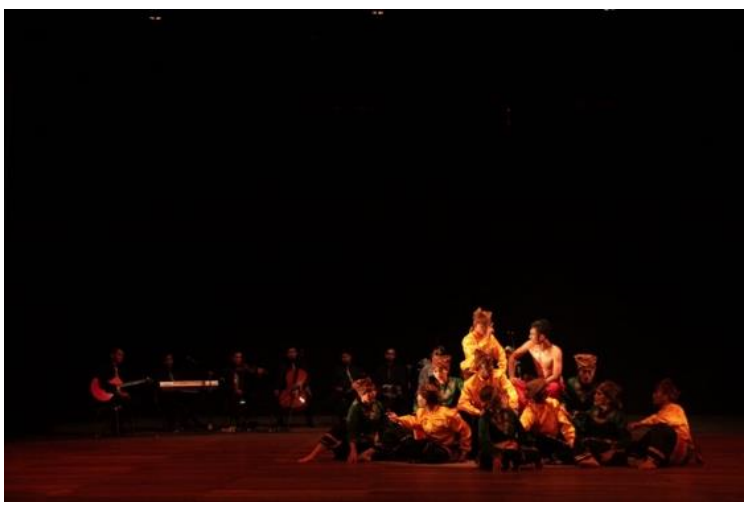

Figure 1. Randai creation in the form of monolog (Yuda, 2018) 


\section{Legaran/ Galombang (Rounded movements)}

Legaran is the main characteristic of a Randai show. It became a distinctive feature of Randai. If there is no legaran in Randai movements, then it could not be defined as Randai. Legaran is a circular motion followed by handclaps, thighs, and galembong. It was functioned as scenes transition or introduction. The movements played in legaran were always followed by a song from Randai singer. The rhythm of the steps and the movements were balanced to the tempo of the music and the rhythm of the song. There were eight to fourteen people in a legaran The basic motion in legaran was Minangkabau pencak silat.

From this aspect, Malin Kundang randai group tried to include choreography as a platform for developing existing movements and patterns in Randai. The developments included changing the basic pattern of a circle into a new pattern such as a triangle, the letter $\mathrm{V}$, the letter $\mathrm{X}$, two circles (small circle of a large circle) and walks alternately to form a tier. These modifications were very helpful in visualizing a Randai. Thus, it seemed that every scene had many motives (Ikhsan Satria Irianto, 2017).

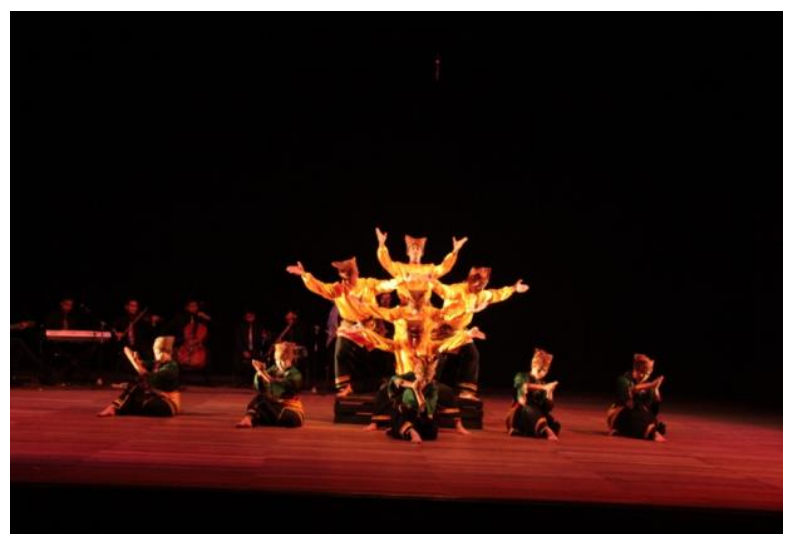

Figure 2. Legaran in tiered formation (Yuda, 2018)

As we know above, legaran was formed in circular patterns by the players by facing each other. The new creation offered was by forming an interesting shape again such as triangles, ovals, rectangles, and other symmetrical patterns. This offer created a new perspective that legaran could be combined with dance choreography. The importance of choreographic was becoming creativity in the development of the basic motion of legaran in which now turned into a dynamic movement of the dancers.

\section{Stories}

Randai story was coming from kaba that developed in the Minangkabau community. The story had a moral message of its customs. Since the beginning of Randai, the title in the Randai manuscript was not taken from the conflict or the area of the story. Whereas it always used the name of the main character in the manuscript, for example, kaba Malin Kundang would create the manuscript title as Malin Kundang too and so were the other texts. Malin Kundang told about a child who was disobedient to his biological mother. He did not want to acknowledge his biological mother because he had been successful overseas and was embarrassed to see his elderly and poor mother. Finally, his mother cursed him into stone because she could not stand her son's jibes.

Further, Randai was usually played by several characters in traditional Randai performances. It included the main characters and supporting characters. However, Malin Kundang randai group introduced monologues technique in delivering the stories (with only one actor who played all the characters). In addition, this monologue technique was also combined with physical theater techniques to create new symbols that guided how stories delivered on the stage. The symbols made Randai be able to empower the literature from the visual representation of the actor. This creation made Randai to be more communicative in a new packaging method. It created a new form of the way how stories conveyed.

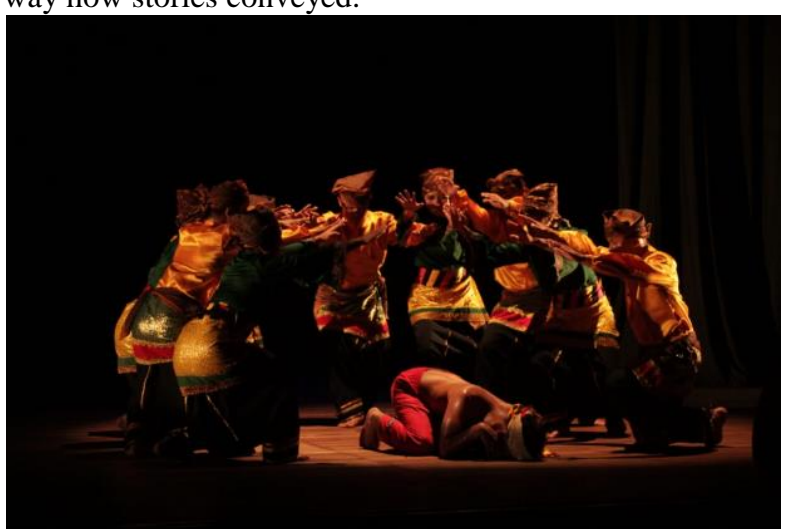

Figure 3. Monologue Randai performance (Yuda, 2018)

The picture above showed the scene when Malin Kundang was cursed into stone. This scene was visualized by involving legaran players as supporting actors at the event. They were becoming a symbol of all social elements who condemned Malin Kundang's cruel treatment toward his mother. In the beginning, it was played by singing a dendang only. Later, it was played through several scenes that could be implicitly understood and served a special attraction.

Moreover, the story was an important consideration to be converted into a new story. Randai always played a wellknown story from its community and this story is familiar to them. They started to hear the story from childhood and even had memorized the flow and dialogue of the manuscript. Based on these observations, the story obviously could not be conserved because it was the soul of the Randai show. It was a literary power identity that had been descended from generation to generation.

\section{Characterization/ Dialogue}

The concept characterizations in Randai also adopted modern theater characters such as antagonists, protagonists, deuteragonists, and other types. They are named jaek figures, elok figures, and also parewa. These types of characters depended on the characters being played. It did not have to be someone who understands about acting, yet she/he at least could memorize dialogue and pronounce sentences correctly. The character problems could be 
adapted to the sentences and can also be used as makeup as a reinforcing element of the character.

In other words, the dialogue was a conversation between characters. The original dialogue of Randai in Minang language was spoken differently as daily Minangkabau community dialogue. Randai dialogue was the form of poetry which certainly brought the beauty of Minangkabau literature. It is interesting since it is not verbal. However, they included many figurative ornaments in the choice of words. Thus, it made sometimes hard for ordinary people to understand what the purpose of the dialogue conveyed by the character.

The dialogue in each scene created by Malin Kundang group was not tied by its literature. However, it prioritizes the implicit message to illustrate the real story happened. The dialogue was more directed to every problem in the scene, for example, the scene of Malin Kundang's ship being attacked by the waves. Using the power of imagination, they were directing how should the events of the ship that were tossed about by the storm visualized. The plot of the story was not only being told through dialogue. It was also supported by the actions of the actors and legaran to make the audience feel the atmosphere of tension oscillated by the storm in the middle of the sea.

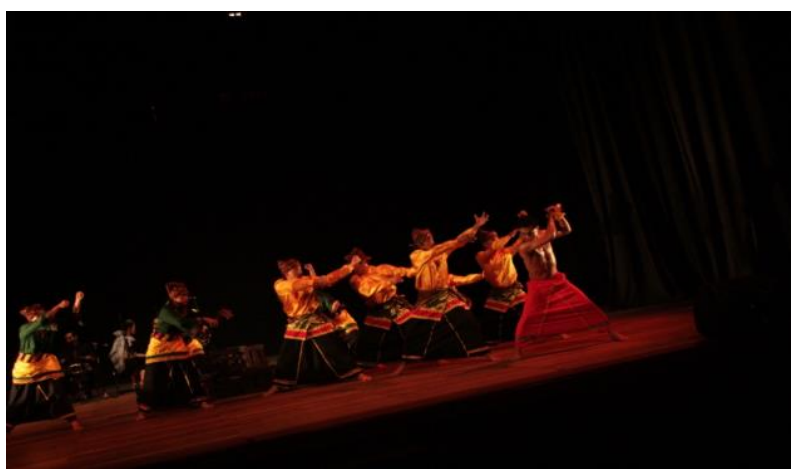

Figure 4. One of dialogue and characterization in Malin Kundang Randai (Yuda, 2018)

The dialogue acted as a communication between the characters who conveyed the story's plot. The way to deliver dialogue in Randai used basic silek, for instance, small steps in each dialogue performed by the characters. This was considered as a new efficient way by giving actors an understanding of acting techniques that was referred to western theory. Basically, the acting technique used in Randai seemed to be rigid and awkward. Thus, making it to be more flexible and natural was a very important point to make Randai enjoyable and pleasant. This western theory was a realism acting theory which represented Randai dialogue seem to be flat. The actors would be taught how to be more expressive and total in using facial expressions using this theory. However, it required special training such as vocal exercise, facial expression training, bodywork, and also mimic exercise to be an expressive actor.

\section{Dendang/ a Song}

Dendang was the art of speech delivered in the form of a song. It consisted of 4 stanzas, the first and second stanzas were called sampiran, while the third and fourth stanzas were contents. Dendang was one of the important elements in Randai show since it was a must to include dendang in Randai. It was used as a tool to narrate the story in the script. Further, there were 3 mandatory dendang called Dayang Daini, Simarantang Randah, and Simarantang Tinggi.

1. Dayang Daini.

Dayang Daini was known as the opening song in a Randai show. It contained greeting and honor for Niniak Mamak, Panghulu, and all the audiences at the location of the performance. One example of the lyrics "mano sagalo niniak jo mamak, cukuik rombongan kasadonyo, jari sapuluah nan kami susun, rila jo maaf kami pintak". This dendang could be meant as begging forgiveness to all customary leaders because all things were coming from humility.

2. Simarantang Randah.

The second dendang was the story song. Every story portrayed was explained through this song. The Randai group background was also being told in this dendang. In sum, dendang could be classified as exposition section in the performance.

3. Simarantang Tinggi.

The high-pitched chant in a Randai show indicated that the show was ended. This part was known as Simarantang Tinggi. Each region had its own lyrics in Simarantang Tinggi, but the rhythm must be maintained.

Therefore, Malin Kundang group still respected the three dendang as the main means for Randai performances. Their beauty in rhythm, tone, and meaning that were delivered so evocative were indeed worthy of appreciation. The new thing that can be done for the creativity process lied in its supporting music. Dendang which was usually only followed by the sound of sauang, bansi and gendang could be combined with western instruments such as cello, electric guitar, drum, triangle, keyboard, and violin. This combination created harmonious tone and professional players additionally. In the end, the audiences were amazed to hear the traditional music instrument combined with the modern musical instrument.

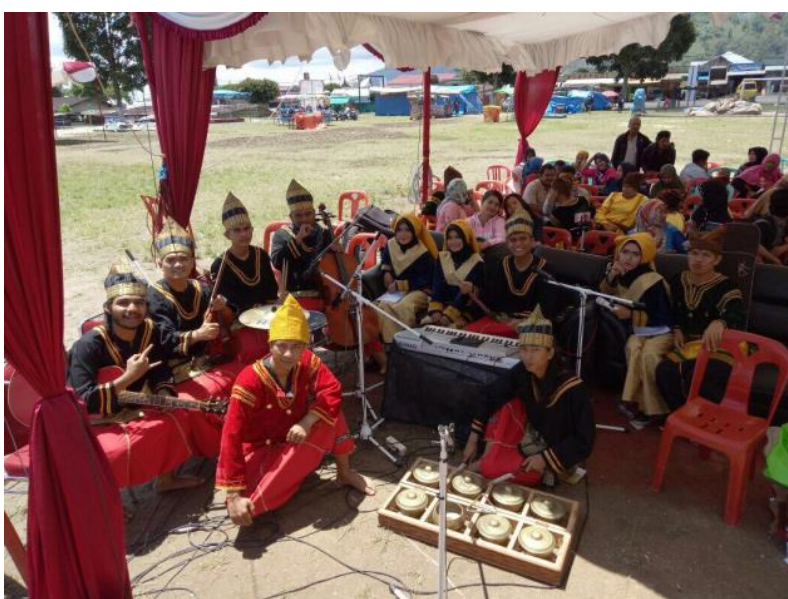

Figure 5. Music combination in Randai (Yuda, 2018) 
In addition, dendang in randai had been patented as it should be because they were important poems delivered through dendang. It had a special role as the opening story, introduction to the story, and also closing. It also acted as a storyteller transition that could not be conveyed by actors because it was limited to a very short duration of time. Even though, its development was done by supporting the traditional music instrument with the modern one because dendang already had its own rhythm. Thus, this combination created a new atmosphere in randai and made a new impression of dendang we were used to hearing. It was becoming a new arrangement and style without omitting its traditional value.

In addition to winning provincial level events, Malin Kundang randai group had also performed in various regions in western Sumatra such as Batusangkar, Padang, Universitas Negeri Padang, and Institute of Arts in Padang Panjang. All the audiences from various regions responded positively to this group due to the new creation offered by them. This concept had also been participated in the Program Indonesia Kaya in Jakarta which was attended by many participants from all over Indonesia. Malin Kundang group was among the top 25 financed in Indonesia Kaya gallery in Jakarta to present and receive training on how to manage a group art with Garin Nugroho.

\section{CONCLUSION}

Preservation is an alternative way, other than many other alternatives. The choice to make development in randai is based on the understanding that traditional arts always develop and they have opportunities to be developed since randai as a traditional art is not a form of art that has been standardized. However, its creations and development must consider the standards of 4 aspects in randai called Legaran, Story, Dialogue, and Dendang.

Randai is widely applied as a base for creating modern artworks, such as theater, music, or dance. From this base, a new development emerged to change an old form into a new modern one. Some of these developments are likely maintaining its original form, while others take randai as the base for the development. Thus, the new creation can be classified as a contemporary direction. The shifting in developing Randai aims to maintain the old values by adopting the new one to make randai more interesting as an art performance than other modern arts.

\section{ACKNOWLEDGMENT}

The researchers would like to thank Universitas Negeri Padang for the contribution in financing this research.

\section{REFERENCES}

[1] Esten, M., \& Hadi, W. (1992). Tradisi dan modernitas dalam sandiwara (Vol. 56). Intermasa.

[2] Harun, C. (1991). Kesenian randai di Minangkabau. Departemen Pendidikan dan Kebudayaan.

[3] Hidayat, S., \& Arkhi, T. S. (2015). The Development of Tourism in Minangkabau Village, Tarusan Kamang, West Sumatra: Attracting
International Tourist Interest with the Traditional Art of Randai. International Journal of Cultural and Digital Tourism, 2(2), 40-49.

[4] Ikhsan Satria Irianto. (2017). Randai Monolog Malin Kundang: Distorsi Randai dan Dekonstruksi Legenda. Retrieved September 1, 2019, from https://www.pojokseni.com/2017/12/randaimonolog-malin-kundang-distorsi.html

[5] Latrell, C. (1999). Widening the Circle: The Refiguring of West Sumatran Randai. Asian Theatre Journal, 248-259.

[6] Manab, H. A. (2015). Penelitian Pendidikan Pendekatan Kualitatif. Kalimedia.

[7] Margono, S. (2005). Metodologi penelitian pendidikan. Jakarta: Rineka Cipta.

[8] Marzam, M., Darmawati, D., \& Mansyur, H. (2019). Tourist Art Packaging Randai Performance in Seribu Rumah Gadang Area Jorong Lubuk Jayanagari Koto Baru, Solok Selatan Regency, West Sumatra. In Seventh International Conference on Languages and Arts (ICLA 2018). Atlantis Press.

[9] Rustiyanti, S. (2014). Musik internal dan eksternal dalam kesenian Randai. Resital: Jurnal Seni Pertunjukan, 15(2), 152-162.

[10] Sari, D. K., \& Wadiyo, W. (2018). The Influence of Socio-Cultural Changes to the Form of Randai Kuantan Art in Kuantan Singingi Riau. Catharsis, 7(1), 87-93.

[11] Sinaga, Fajry Sub'haan Syah. (2016). Musik Trunthung Sebagai Media Ekspresi Masyarakat Warangan. In Seminar Antar Bangsa (pp. 161174). INA-Rxiv. https://doi.org/10.31227/osf.io/ wc4vy

[12] Sinaga, Fajry Subhaan Syah. (2016). Transformasi Musik Trunthung dari Pengiring ke Pertunjukan di Dusun Warangan, Kecamatan Pakis, Kabupaten Magelang. Universitas Negeri Padang.

[13] Syah, F. S. (2013). Kesenian thek-thek walisongo di kelurahan tritih kulon Kecamatan Cilacap Utara Kabupaten Cilacap: Kajian Tekstual (Bentuk Pertunjukan Dan Komposisi Musikal). Jurnal Seni Musik, 2(1).

[14] Wendy, H. S. (2014). Dramaturgi Teater Rakyat Randai Di Minangkabau. Jurnal Kajian Seni, l(1), 32-47. 